\title{
Show me the Prison! The Development of Prison Tourism in Britain
}

\section{Abstract:}

This article presents an analysis of the historical development of prison tourism in Britain and the ways in which prisons are currently represented via prison museum websites. While there has been significant examination of various prison museums overseas there has been comparatively little published on these institutions in Britain. In response to contending pressures, prison museums have endeavoured to present a balanced and objective depiction of past prison systems whilst their promotional websites, which serve to draw in customers, frequently rely on 'popular' depictions. These representations raise important questions as prisons cannot be seen as neutral or apolitical, neither those in the early twenty-first century nor those of the past. Despite these pressures, prison museums have great potential to increase public understanding of the prison and this article promotes a more ethical, multi-perspective and politically diverse interpretation within prison museums.

Key words: Prison, tourism, representations, media

\section{Introduction:}

The 'spectacle' of punishment did not diminish with the shift from corporal to carceral sentences. Rather it endured in the form of mediated representations of the prison (Sparks, 1992) and through these sources the prison enjoys far greater visibility than ever before in its history (Cheliotis, 2010). Widespread media representations have managed to absorb the prison into popular culture (Wright, 2000) and, it has been 
suggested, via particular methods of strategic management, have served to consolidate punitive attitudes in the public consciousness (Cheliotis, 2010; Mason, 2006a; Mathiesen, 2006). Criminology has embraced the study of the representation of the prison through various forms of media, for example news reportage (Ryan, 2006), film (Bennett, 2006a; Mason, 2003, 2006a; O’Sullivan, 2001), TV drama (Chibnall, 2006; Jarvis, 2006; Jewkes, 2006) and documentary (Bennett, 2006b and 2014). However, one form of mediated representation has received comparatively little attention, in the UK at least. Prisons as tourist attractions are an increasing, although not new, phenomenon. Prison tourism can be considered as part of the broader practice of so-called 'dark' tourism. Dark tourism refers to visits to locations that embody suffering, tragedy, violence, disaster or death; the emphasis on the latter means it is often identified with the broader 'thanatopic' tradition (Foley and Lennon, 1996; Sharpley, 2009; Stone, 2006). Constituting an eclectic range of sites and attractions, the phenomenon is extremely difficult to classify and theorise (Stone, 2006). For example, as forms of dark tourism, locations can invoke sombre reflection, grief, sorrow, shock and horror. But as tourist ventures, they may simultaneously offer excitement, enjoyment and entertainment for the visitor (Sharpley, 2009). Some sites are intentionally organised and marketed for visitors or tourists (holocaust or genocide museums for example) whilst others develop through a more spontaneous process (for example, places of infamous murders such as the home of Fred and Rosemary West in Cromwell Street, Gloucester or the town of Soham where Holly Wells and Jessica Chapman were murdered in 2002). Driven by a desire to memorialise, and/or by consumer demand, some venues shift from sites of public interest to organised exhibitions (such the 'ground zero' site in New York). Because of its diversity (in terms of location, features, historical importance and 
supply and demand motivations) Stone (2006: 146) determined that dark tourism cannot be conceptualised as a holistic project. Rather it must be imaged as a 'fluid spectrum of intensity' with the 'darkest' sites (places of suffering and death, for example battlefields or sites of genocide or mass killing like Auschwitz-Birkenau) at one end and the 'lightest' sites (places associated with suffering and death however loosely - for example the London Dungeon or the Dracula theme park in Romania) at the other. The darker sites, he contended, would generally be recognised as authentic (in terms of both product and location) and, being ideologically and/or politically inspired, would be focused around commemoration or education. By contrast, those sites at the lightest end of the scale would be less (or in-) authentic, firmly entertainment focused and commercialised. In the middle of his typology, and thus representing a combination of education and entertainment, are what Stone refers to as those sites that 'present bygone penal and justice codes to the present day consumer' (2006: 154), primarily former prisons.

Prison tourist sites are frequently referred to as prison museums in that they are generally concerned with the conservation and display of architecture and artefacts of historical, social and/or cultural importance or interest and thus share many of the features of standard museums. As with standard museums, and indeed other dark tourist sites, the reasons for the preservation of structure and/or objects can range from purposes of aesthetics, education and conservation to entertainment and commercial profit. As 'dark' sites, prison museums also represent histories of human pain, suffering and, sometimes, death (Sharpley and Stone, 2009). Further, these are histories of suffering and death via legitimised punishments, the ultimate manifestations of state power. Thus, like many dark tourist sites, they present a series of ethical conflicts. Whether the aim is education, commemoration or 
entertainment, dark tourism involves the commodification of those who have suffered or died (Sharpley, 2009). This affords prison museums a political dimension (whether it is acknowledged or not) and, arguably, a profound responsibility in respect of the authenticity and ethics of representation.

Some dark tourist sites offer visitors a means to 'integrate themselves into the objects of consumption' (Sharpley, 2009: 18). Unlike TV and film representations, the prison tourist site presents an opportunity for the public to directly enter the world of the incarcerated and therefore has the potential to offer a more affective, edifying and profound experience than other forms of media or cultural representations. Such sites can '[invert] many of punishment's fundamental properties. Culturally invisible, the [prison] is...rendered visible. Fundamentally closed and exclusionary, it [becomes] open and accessible...' (Brown, 2009: 91). The emotive power of visitors being able to physically enter a prison, or part of it, has been recognised and indeed replicated as a campaigning strategy by activists who seek to challenge received perspectives of prisons and punishment and keep debate on imprisonment alive. Most recently Rideout have toured with their exhibition GOTOJAIL, an 'inhabited' cell that 'pops up' in shopping centres, festivals and arts venues. GOTOJAIL enables the public to experience that most fundamental of prison spaces: the cell. As Saul Hewish, a co-director of Rideout, stated in a recent interview, 'You get to experience both what a contemporary prison cell looks and feels and sounds like' (Fiddler, 2013: 41). Crucially this project also enables members of the public to talk to 'prisoners'. Prisoners in the GOTOJAIL cells are actors but actors who have been in prison and so able to draw on their direct experience offering a 'much more visceral engagement' (Fiddler, 2013: 41). The constructive recreation of the prison cell is not new. Perhaps the best known historical example is provided by the suffragette 
movement. In May 1909 a mock cell was erected at The Women's Exhibition at Prince's Skating Rink, Knightsbridge in which a member of the movement, who had actually been to prison, demonstrated the daily duties carried out by suffragette prisoners. The purpose was to highlight the conditions in which suffragettes were being held and their treatment as 'common criminals'. ${ }^{1}$ In both of these examples (one historical, one modern), the primary aim is to bring an authentic recognition of the exigencies of prison life closer to the visiting public rendering aspects of the prison, in this case the cell, more physically and emotionally visible.

But whilst it may offer the possibility of direct engagement, prison tourism also presents an opportunity to '...write or re-write the history of people's lives and deaths, or to provide particular (political) interpretations of past events' (Sharpley 2009: 8). Within prison tourist sites the emphasis is overwhelmingly on prison history and representations of incarceration regimes of the past, of things, therefore, seemingly 'dead' (Brown, 2009). Numerous cultural descriptions and representations have drawn on the prison as a metaphorical form of death. Charles Dickens described the separate system at Eastern Penitentiary as akin to being 'buried alive' (Johnston, 2006: 108). Prison cells have been conceptualised as places of death or 'entombment' (Jewkes, 2012). Whilst prisoner autobiographies have often evoked an image of prison life as a 'living death' (Balfour, 1907: 110; Brown, 2003: 20) and inmates as 'dead men in prison' (Macartney, 1936: 205). But the prison is not a static, 'dead' relic of the past. The prison is persistent, it has endured across the centuries and, despite being considered ineffective ${ }^{2}$ and

\footnotetext{
${ }^{1}$ Exploring $20^{\text {th }}$ Century London, 'Suffragette stand at the Women's, Knightsbridge Exhibition' http://www.20thcenturylondon.org.uk/mol-in115.

${ }^{2}$ Numerous studies have indicated that prison has not, historically or contemporarily, acted as a deterrent (see Morris and Rothman, 1998; Burnett and Maruna, 2004) and that recidivism rates are very high even when rehabilitative programmes have been attempted (Mathiesen, 2006, 2013; Scott and Codd, 2010).
} 
(individually and socially) harmful ${ }^{3}$, it is used more than ever before and with considerable public support (Mason, 2006b; Monteresso, 2009). As Welch and Macuare (2011) note, representations of 'dead prisons' can (re)construct understandings of contemporary prisons within the public imagination. They can become 'monument museums' (Walby and Piche, 2011: 452) that represent and even replace their actual structures in the public consciousness: their interpretations becoming forms of reality for the viewing audience. Prison tourists are not simply looking at a collection of neutral objects within a museum (nor are they looking at objects neutrally). Rather they are involved in a project whereby the present draws upon its history 'in order to construct its modernity' (Prior, 2002, quoted in Welch and Macuare, 2011:420). For these reasons the depiction of prison history in prison museums is of fundamental significance in terms of shaping understandings of contemporary penality in the minds of the spectator.

It is the intention of this article to interrogate the 'visibility' of the prison as manifested by its tourist status. We will take an interdisciplinary approach to the subject, considering prison tourism from within historical and criminological perspectives. As we have stated previously, prison tourism is not a new phenomenon yet very little has been written about its history. An historical approach illuminates the dynamic relationship between the public and the prison over time and contextualises the nature of contemporary tourist engagement. Additionally, it establishes key approaches and parameters from which contemporary museum professionals have drawn. Whilst the academic discipline of history has contributed

\footnotetext{
${ }^{3}$ Rates of self-inflicted deaths, self-harm and interpersonal violence underline the individual harm that prison causes (Corston, 2007; Leibling, 1995, 1999; Scott and Codd, 2010). Additionally, nationally and internationally, historically and contemporarily, a direct relationship between imprisonment and 'crime' rates has not been unequivocally established (Downes, 2007; Scott, 2013). Instead it is widely recognised within criminology that the prison has functioned to segregate and control specific groups in society (Bell, 2013; Davis, 2003; Lacey, 2008; Mathiesen, 2006; 2013; Parenti, 1999; Simon and Feeley, 1992; Wacquant, 2009).
} 
much to analyses of the prison, it has contributed much less to the analysis of tourism, which seems strange given the importance of the phenomenon and its long historical existence (Walton, 2005). On closer inspection what has occurred is a lack of historical exploration of the systematic development of tourism or, to be more precise, concentration has been on particular subject areas, for example The Grand Tour or the growth of seaside and resort towns (for example, Black, 2003; Cross and Walton, 2005). In part this can be explained by the division between history and heritage which must surely have mitigated against what has been cited as the need for a 'systematic framework to explain the tourist phenomenon in its various manifestations' (Burkart and Medlik, 1981: vi).

This article will also examine some particular elements of contemporary prison tourism in the UK from a critical criminological perspective. Prison tourism is an international phenomenon and has been quite extensively analysed as such (see for example Adams, 2001; Loo and Strange, 2000; Strange and Kempa, 2003; Walby and Piche, 2011; Welch, 2012, 2013; Wilson, 2004, 2008). However there has been little (criminological or historical) academic interest in this form of 'dark' tourism in the UK. This paper represents an initial investigation into the field. We do not present an analysis or audit of physical prison tourist sites as a whole. Instead we explore the ways in which prison museums and tourist locations are presented to the public via internet sites. This is often the first route by which members of the public are introduced to these tourist spaces (Kravchyna and Hastings, 20024; Marty, 2007). Thus we analyse the dominant themes and tropes that are used to depict prisons, prisoners and prison life, in order to attract public interest. The article will go on to question the extent to which the visibility of the 'tourist prison' can illuminate the

\footnotetext{
${ }^{4}$ Kravchyna and Hastings found that most people in their study visited museum websites before and after an actual visit.
} 
reality, as well as the official rhetoric, of state punishment and thus enlighten or educate a viewing audience about penal modernity.

\section{Historical developments}

Media representations have made the prison increasingly visible but the prison has long composed part of a broader institutional spectacle, including hospitals and asylums. Since the eighteenth century these institutions have been important elements of the emerging civic landscape. Among early visitation of carceral institutions could be cited Bedlam asylum but the purpose of such visits was more to observe, and possibly be amused or shocked by, the strange behaviour of the inmates than to learn about the operation or efficacy of the institution itself (Arnold, 2008). ${ }^{5}$ Similarly, the perviousness to visitors of debtors' prisons like the Marshalsea, Fleet Prison and King's Bench Prison, was primarily about supplying and supporting those imprisoned not about leisure or even education. Nevertheless, White has emphasised objectionable aspects of visiting prisons during the eighteenth century and suggests that prisons in London developed a sort of 'fascination, even a perverse glamour': 'Many were drawn to visit the prisons, especially Newgate, as one of the shows or 'lions' of London, for the gothic sensation of the fearful sights to be seen there' (White, 2009: 76). A more respectable form of institutional visiting is evidenced by teenage Charles Powell who visited Maidstone Gaol a year after Daniel Asher Alexander's monumental radial structure had been completed in 1822 (Brodie et al, 2002: 67-70). He observed how they

\footnotetext{
${ }^{5}$ Bethlehem Hospital or more commonly known as Bedlam is the world's oldest psychiatric hospital. Founded in 1247 , its long history has been used as a means to examine changing attitudes to the mentally ill (Arnold, 2008).
} 
Arrived at Maidstone at 4 o'clock to Bell Inn, Papa came in soon after us, then we all walked to the New Jail a fine stone building went into the wards and chapel - saw the prisoners spinning, weaving, making mats, string, ropes, etc., then we came in to dinner (cited in Brodie et al, 2002: 67).

At the end of his day's visit he concluded that: 'Maidstone seems a large town and the Jail a large, strong, melancholy and clean place of punishment' (cited in Brodie et al, 1981: 67). Charles Powell's diary makes it clear that he and his father were curious about a range of places and structures but that Maidstone Prison formed a part of the educational and entertaining sights to be seen (Brodie, 2014). Some prominent large institutions and their innovative designs were interesting because they reflected what was heralded as enlightened and experimental approaches; they were show pieces for the control and reform of particular sectors of the population. The original designs for what later became Dartmoor Prison, but began life as a structure to contain prisoners of war, were published in Ackermann's Repository in September 1810 and attracted considerable public interest.

During the nineteenth century those gaining access to prisons generally were, or were reporting to, people of some substance, viewing and appreciating the products of progressive penal philosophies and civic pride. Journalists reported on this new mode of living, often supporting it as an unquestioned mark of civilisation, although there was also significant and diverse criticism of the new 'model prisons'. For example, Thomas Carlyle and Charles Dickens were prominent critics. A story about Pentonville Prison published in The Essex Standard and General Advertiser for the Eastern Counties (11 October 1844) was effusive regarding the efficiency and indeed 'triumph' of humanity represented by the 'whole contrivance of the building' 
and the discipline about which there was 'some fascination' but also the strangeness of the reformative prison environment. It was a 'curious sight' to see 'steams of human beings, all dressed alike, with vizors of their caps drawn down over their faces...marching regularly, steadily, and in perfect silence.' The prison divide was absolute and unquestioned, it established a 'brick-wall' defining 'the moral antipodes' of a criminal class with 'coarse and hardened features of habitual soul-destroying wickedness.' These journalistic visitors wrote about the prison as though they were explorers into the unknown, examining the new science of imprisonment.

Public fascination with these new carceral structures and what went on behind their walls persisted. Unlike in previous eras, when punishments aimed to deter deviant behaviour through visual display and public access, in the new modern prisons it was concealed. The 'civilisation' of punishment from the nineteenth century meant the practice became increasingly anonymised and remote from the public gaze. But whilst the imposition of punishment was obscured, the threat remained visible via the structure of the prison itself. When prisons were used simply as holding venues their external structures were of little importance. But with the demise of public forms of punishment, and prisons becoming places of punishment in their own right, prison structures became the 'spectacle' (Pratt, 2002), enhancing the sense of segregation of the criminal from the outside world (Evans, 2010). Their external architecture, laden with symbolic decoration such as carvings of manacles, fetters and gargoyles, relayed messages about their internal operations (Pratt, 2002). Designed to project a message, the façade tapped into the 'imaginative and expressive capacities of architecture' (Fiddler, 2011: 87). Expensive and extravagant, they represented the incontrovertible power of the state. As Evans (2010) comments, vindication of the prison has long been sought from outside of its 
walls. Its effect on the public - on deterrence and conscience -forged its legitimacy. In other words 'It was the dramatic character of incarceration that gave it its value' (Evans, 2010: 76). Thus, deterrence became enshrined in the fabric of the institution with impressive and awesome structures that transmitted unequivocal penal messages which, in turn, elicited direct emotional responses from the public (Bender, 1987). Well-known prisons, such as Pentonville and Dartmoor, attracted large numbers of visitors merely to observe from the outside and appreciate the power of the external architectural and moral structure (Barton and Brown, 2011). Pentonville was extremely influential nationally and internationally and heralded as the most advanced building of its day (Evans, 1982: 367). This kind of fascination with the prison wasn't interpreted in any structured manner until quite late, in part no doubt because it continued to be depicted as part of a cultural education rather than as a form of entertainment, which would have been perceived as less salubrious and tainted by the subject of crime. An article in the Illustrated London News (1 December) in 1884 observed both the close relationship between Dartmoor Prison and Princetown village and the number of tourists to the village but made no link between the tourists and the prison. Certainly when the link between an operating prison and tourism was recognised it was sometimes viewed with distaste. In a 1957 article entitled 'DARTMOOR PRISON "NOT A ZOO", Prison Commissioner and former deputy governor of Dartmoor Prison, Duncan Fairn, registered a 'strong protest' against what he called 'this monstrous business' which was 'a menace to the work of the prison' and 'a disgrace to our people.' According to Fairn, 'tourists' not only drove up to the prison but clambered up the walls and shouted 'Look, there's a convict; look there's another one' (Times, 14 March 1957). But prisons did appear in guidebooks from an early point. A Guide to Lincoln Castle and Grounds published in 
1898 observed that the Victorian prison within the grounds was closed but described the separate system chapel in such detail that it suggests that it was open to the public. By 1927 a guidebook for the same prison stated explicitly that the 'cells and the Chapel are now open for inspection'. The use of the term inspection is interesting in that it implies examination or scrutiny for educational rather than entertainment purposes. The prison chapel in Lincoln appears to have remained open to the public ever since. ${ }^{6}$

Possibly the earliest and best documented example of a dedicated and commercially-oriented prison museum is the exhibition ship 'Success' which was consciously promoted in a sensational manner to cater to public fascination with the seamier, more gruesome and dramatic aspects of incarceration. But its promoters also asserted the educational value of visiting the ship to enhance understanding of the transportation system. 'Success' was advertised widely, internationally and erroneously as having transported convicts from Britain to Australia, stirring considerable interest. The ship was built in 1840 in Burma, began life as a trading ship and made three voyages from London within the decade carrying emigrants to Australia. On 31 May 1852, 'Success' arrived in Melbourne and, following the desertion of its crew to the gold-fields, was purchased by the Government of Victoria for use as a prison hulk. She was used to incarcerate convicts (she never actually transported convicts) for a relatively short time, possibly less than five years, although thereafter she was used as a reformatory. In 1890, 'Success' was bought by a group of entrepreneurs and began fifty-five years as a prison exhibition ship around Australia, the United Kingdom and America. In the United Kingdom advertisements promoting the ship as an attraction described her as 'unique' (Times,

\footnotetext{
${ }^{6}$ Thank you to Helen Bates and Susan Payne of the Lincoln Castle Revealed Project for their information and advice.
} 
7 December 1895), a 'Museum of curios'; a 'Magnificent museum' on which you could hear 'Thrilling lectures' (Manchester Guardian, 9 April 1912).

According to Tit Bits (12 March 1896) it 'simply had no competition' and was the 'Most remarkable ship that ever visited London'. Late in 1898 the ship was in Dundee and the Dundee Courier (12 December 1898) listed scenes on board, including, 'CONVICTS ATTEMPTING TO ESCAPE', 'CONVICTS AND WARDERS IN THE ACTUAL DESPERATE STRUGGLE FOR LIFE', 'RIOTS', and a waxwork of 'NED KELLY THE BULLET-PROOF RANGER, AND HIS ORIGINAL SHOT INDENTED ARMOUR', although he had never been confined on the ship. The exhibition attracted a wide range of visitors including Prince Henry of Battenberg (Lloyd's Weekly 10 November 1895). By 1897 the ship was in Belfast at which point an extensive and vivid account of the exhibition appeared in the Belfast News-Letter (7 October 1897) no doubt drawing from the 'very graphic' account written by Joseph C Harvie. Harvie was manager of the syndicate which owned the ship and his account was available as a guide to visitors:

The Success is no dream, no conjured spectre of the fancy, but, in so far as associated with a past and regrettable period of our colonial history, a tangible and gruesome relic of the vilest and most revolting forms of torture possible for one man to inflict upon another. This truly curious vessel, which may, deservedly be pronounced a monument of human brutality. ${ }^{7}$

We can see in the Success exhibition evidence of the more sensationalist tendencies of some later prison museum exhibitions. The passage of time lent the

\footnotetext{
${ }^{7}$ Anon, The Convict Ship "Success": The Last "Floating Hell", republished from 1876 edition, www.digitalantiquaria.com. Thank you to Dr Chris. A. Williams for highlighting the availability of this publication.
} 
commercially-driven site a license to exaggerate and even fabricate experience. The depiction of later developments in penal policy as reformative progress also enabled a sensationalist approach to the supposedly less civilised past and in that sense makes some claim to be educational. The prison ship Success was exploited not only as an opportunity for visitors to consume the past as a form of entertainment in which past lives and penal mechanisms were manipulated to emphasise the sensational, gruesome and, to an extent fictitious, events but also almost as a educative memorial to a shameful past from which a civilised nation had progressed. Criminal relics, not necessarily associated with the ship were brought together as curios rather than to attempt to reconstruct an authentic, dedicated exhibition. The commercial imperative took precedent and the extensive promotion of the exhibition brought a range of people in to view it and be a part of the adventure of crime and punishment from the past. From a relatively early historical point promotion fed on the notion of progress and modern civilised methods of punishment and juxtaposed this with a simplistic view of an excessively punitive past.

The concept of a museum dedicated to the prison, and indeed which had been a working prison, was not new to the twentieth century. Nor in fact was the link between the prison and tourism since people had been travelling to view modern prisons since they were established even if it was not always recognised as a form of tourism. The powerful political dimension that could be inherent in the conversion of a once operating prison into a museum was signalled early in the twentieth century in relation to Kilmainham Prison, Dublin, which closed in 1924. Endeavours to open the prison to the public were driven by its potential as a site of memorial. Irish nationalists from conflicts in 1916 and 1922 had been imprisoned, executed and buried there. In 1938 an open day at the prison attracted 'vast crowds' and guides 
told visitors 'vivid stories... of escapes, executions and famous men' (O'Dwyer, 2010: 40-3). As a result of the efforts of a voluntary group restoration work finally began in 1960 and the site was opened as a museum in 1971. The evocative and political power of the location is undeniable. According to one account, this 'site of oppression has become central to the mythos of the Irish Republic', but it has also been pointed out that 'ordinary' criminals such as thieves and prostitutes have received 'short shrift' in this exhibition (Levin, 2005: 84). Levin has criticised the lack of examination about oppression on the basis of class or religion, two of the political dimensions which have underpinned all prisons. However, in the context of the particular history of Kilmainham, Levin asserts that the museum has been instrumental in reimagining Irish history; that the museum 'reshaped the notion of Ireland as an island racked by internal strife into a heroic narrative of independence' (Levin, 2005: 84-5). These comments resonate with debates which have beset the development of historic prisons well-known for incarcerating political prisoners, such as Robben Island and The Maze.

The economic utility of prisons as tourist attractions and how that was perceived differed depending on the prison and its location. Historically, Dartmoor Prison presents a particular case of co-operation and even symbiosis between the prison and the local community, in Princetown the small town adjacent to the prison. An enquiry into the future of Dartmoor in 1960 recognised that Dartmoor Prison was an 'immense tourist attraction.' Indeed David Foot Nash of the Dartmoor Preservation Association stated that the prison was 'part of the Moor's attraction, history, appeal and fascination...It is just the one Dartmoor site the visitor does not want to miss' (Daily Mirror 29 April 1960). In an article of 1962 Charles FletcherCooke, Joint Parliamentary Under Secretary for the Home Office, surmised, 'It is 
most extraordinary, but prisons are tourist attractions' and using the example of Dartmoor he continued 'I have tried to persuade people on the Isle of Man to have a prison. They say the tourists will be frightened away. Quite untrue. It is like a casino. It is a great attraction' (Guardian, 29 August 1962).

In 1973 the appeals organiser for NACRO suggested the integration of prisons more fully within the community, which would, he envisaged, reduce the drain on public resources through tourism. Perhaps slightly with tongue-in-cheek but still making an important point about the economic potential of prisons, he speculated that with 'imagination and flexibility' tourism could be one of the 'instruments' by which prisons could 'become power houses of community resources' in the 'stately homes league'. Prisons then could become economic assets (Times 2 February 1973). Others disagreed. The Norman castle in Lancaster was already a draw for tourists. In 1975 the use of Lancaster Castle as a prison was seen as only inhibiting tourism, because it prevented access. An article titled, 'A clash of castle and cell', asserted that 'Visitors to Lancaster complain that they cannot get inside the castle because it is still used as a prison' (Guardian, 24 February 1975). Lancaster Castle had served as a prison until 1915 but then, faced with a shortage of prison accommodation during the early 1950s, the Prison Commission approached Lancashire County Council with a preliminary enquiry about reopening it as a prison, which took place in 1955. The Manchester Guardian (5 December 1952) commented that 'Judging from local reactions this week the citizens are not all entirely happy at the prospect of five hundred rather special inhabitants moving into the big stone building in the city centre.'

By the 1990s dedicated prison museums were a part of the heritage landscape, evidence of what has been called Britain's apparent 'insatiable curiosity 
about crime and punishment' (Guardian, 24 September 1993). They have been defined within a historical context bringing a range of competing influences and trajectories as well as contemporary stakeholder interests and heritage objectives. Certainly, the likely interest in prisons being converted into museums and the level of their consequent success is in large part dependent on the history of that individual prison. ${ }^{8}$ The historic development of prison tourism reveals the persistent tensions between such institutions as serving entertainment or educational purposes. Yet the dividing line between these rationales has remained blurred and open to manipulation.

\section{Contemporary prison tourism in the UK}

The contemporary prison tourist industry in the UK generally consists of decommissioned institutions which have been converted into some form of visitor attraction. As has been the case historically, the physical structure of a prison is immensely important in this form of tourism. Seeing a prison building for the first time is, for the tourist '...a visually defining moment [whereby] [l]ooking becomes an outright compulsion' (Brown, 2009: 100). By the mid-twentieth century prisons were designed with anonymity, rather than visibility, in mind. Located outside of towns and cities their design was functional, bland and not dissimilar to regular office buildings. But these new designs, through stark contrast, amplified even further the familiar 'see and beware' symbolism inherent in the architecture of the old Victorian institutions (Jewkes, 2012: 33)). As Urry (1990) contends, inherent in the tourist 'gaze' is the power of judgement. This can be shaped not just by what the tourist

\footnotetext{
${ }^{8}$ The history of individual historic prisons must be a key part of current debates regarding the future of those which have been recently closed. For example, see http://www.bbc.co.uk/news/uk-20969898.
} 
sees but what s/he expects to see (Buddhabhumbhitak, 2010). Thus, not surprisingly, the prisons that now have a second life as tourist attractions in the UK are, without exception, those that fit closely with an expected architectural form. These include Beaumaris Gaol in Angelsey, Bodmin Gaol in Cornwall, Crumlin Road Gaol in Belfast, Derby Gaol, Inveraray Gaol in Argyll, Littledean Jail in Gloucestershire, Nottingham Galleries of Justice, Ripon Gaol in Yorkshire, Ruthin Gaol in North Wales and York Castle Prison: all nineteenth century edifices which are iconographic symbols of segregation, isolation and the state's power to punish. ${ }^{9}$ Two notable exceptions are the London Clink and HMP Dartmoor. The former differs from those listed above as it is a purpose built site constructed at the location of the original debtors' prison whilst the latter is atypical because, whilst it certainly fits with the monolithic Victorian standard, it is an operational institution which does not offer public access tours but does have an identifiable tourist focal point in the form of a museum, converted from the old prison dairy.

All of these establishments have dedicated websites, except for Beaumaris and Ruthin Gaols. Information about these two sites is found via the Anglesey tourist website and the Denbighshire County Council website respectively. Some sites clearly identify themselves as museums or heritage centres (for example Beaumaris, Inveraray, Ripon, Ruthin, Clink and Dartmoor) emphasising (to varying degrees) a factual or educational history of the prison. Others are advertised more explicitly as tourist attractions, emphasising their commercial potential as "all weather family attraction[s]" with bars and restaurants (for example Bodmin), as

\footnotetext{
${ }^{9}$ Some of these prisons may include sections that date from earlier or later periods of history. However, their main buildings were constructed during the $19^{\text {th }}$ Century and thus their architectural style is typical of that period.
} 
venues for public events (Crumlin Road) ${ }^{10}$, or as venues for a range of eclectic exhibitions, sometimes completely unrelated to the prison (Littledean Gaol) ${ }^{11}$.

Regardless of whether it is education or entertainment that takes precedent on the websites, what is noticeable is that, almost without exception, they use similar devices in their representations of the prison. Their depictions draw largely on prevailing popularist imagery around the prisoner as the aberrant 'other' and a stateendorsed narrative around the prison as a historically harsh but, nonetheless, apposite and necessary response to 'crime'. The emphasis on history also serves to infer an ideology of penal progressivism; emphasizing the brutality of bygone punishment which, arguably, sets a misleading benchmark from which visitors can judge contemporary incarceration regimes.

Whilst we have noted above that an analysis of actual physical prison tourist venues is beyond the scope of this paper, one important (albeit anecdotal) point about them should be mentioned. From our own experiences, it is apparent that some venues rely much less on dominant stereotypical imagery in their physical sites than on their respective virtual (web) sites. Physical sites obviously offer a much fuller sensory experience than websites: visitors can engage with an ambient and tangible environment much more expressively than they can with a virtual environment. Also, physical sites have more physical space to present displays and narratives thus allowing supplementary information and context to be provided for the visitor. Tourist websites, by comparison, are designed to be viewed for a much shorter period. They are used to provoke initial interest, to inspire the 'virtual' tourist to visit a museum in person (Marty, 2007) and research has demonstrated that, for a

\footnotetext{
${ }^{10}$ Crumlin Road offers a conference centre and, at the time of writing, a series of tribute act nights.

${ }^{11}$ Littledean Gaol is described on its website as "Europe's largest true crime, politically incorrect, bizarre, diverse museum and visitor attraction" and has exhibitions on 'mafia and gangsters', 'Nazis', the Ku Klux Klan, the SAS, 'freaks of nature' and 'celebrity sleaze and scandal'.
} 
significant number of tourists, a visit to an actual museum is prompted by a visit to its website (Kravchyna and Hastings, 2002). ${ }^{12}$ Thus it would seem that in order to encourage visitors, even those prison museums that try to present a more informative and educational history, are compelled to rely on stereotypical depictions of the prison, prisoners and punishment as these are the images that are most familiar to, and most readily and rapidly accepted by, the public.

By opening the otherwise closed world of the prison to the public, prison museums could potentially be used to challenge dominant, popular stereotypes and ideologies. They have an occasion to present the visitor with the personal, emotional and psychological aspects of imprisonment, as well as the broader historical and structural contexts within which it has developed and exists. But this is immensely difficult, whilst punitive attitudes are so heavily socially entrenched. Thus, we argue, even if it is the intention in some physical prison tourist sites to underplay gratuitous and stereotyped depictions of the prison and prisoners, website imagery and narratives undermine this effort and instead, like many other types of media depictions, serve to endorse and reinforce common sense ideologies amongst the viewing public.

What follows is an analysis of some of the conventions of penal imagery used in prison tourist websites and the ways in which they can serve to construct (mis)understandings of penality and penal modernity.

\section{Representations of the prison, prisoners and prison life}

According to Foucault (1977), the prison was originally defined by the process of looking - by the 'gaze'. The prison tourist gaze acts similarly: it is constructed around

\footnotetext{
12 This research was conducted on the usage of regular museum websites by the public.
} 
the notion of difference - the witnessing of an alien or unfamiliar experience. The pleasure and comfort in this process is gained by knowledge that the "hierarchy of the gaze' is not disrupted - in other words, there is no possibility of being looked back at or challenged (Brown, 2009: 97). The tourist remains protected from punishment's 'most fundamental feature ... its infliction of pain' (ibid: 9). But whilst tourists might want a 'safe' experience, when visiting a prison, they do not expect a completely passive encounter. Attempts to address this, to represent the 'reality' of prison life in the (relatively) static environment of a vacant prison structure is problematic and the difficulties are further intensified when representing the prison via websites. The internal life of any prison, past or present, is extremely complex. Prisons operate around intricate and often contradictory interpersonal and institutional dynamics and power relationships (see Bosworth, 1999; Welch, 2005, Scott, 2013), which are difficult to decipher and represent. So in prison tourist sites a process of selection necessarily takes place with regard to the portrayal of elements of prison life. What is often the result is not so much a representation of 'reality' but rather an 'imaginary' depiction (Carrabine, 2012) of the prison and of the individual, and collective, experiences of prisoners. Processes of simplification, generalisation and exaggeration are used conjunctively to simplify complex realities for the purposes of the audience and, arguably, to avoid confrontation with hegemonic state defined narratives of imprisonment which would raise further complexities.

Prisoners are not solely incarcerated individuals; they have identities that transcend any criminal or legal status but on tourist websites, their depiction mirrors that found in other dominant and familiar 'files of representation' such as films, TV programmes and novels (Strange and Kempa, 2003: 387). As Brown states, in the prison tourism project 'expert' knowledge often 'fight[s] a losing battle against 
popular culture' (2009: 101-2). ${ }^{13}$ In website depictions, prisoners become onedimensional; presented as singularly strange and unique yet, simultaneously, as collectively similar and familiar. Their characterisation is predicated on popularised perceptions of criminality. One way this is achieved is by the emphasis on the (in)famous or 'celebrity' prisoner. Dartmoor prison museum website, for example, invites visitors to '[l]earn all about notorious past residents including Frank Mitchell and John George Haigh'. ${ }^{14}$ At Nottingham Galleries of Justice visitors can attend an exhibition based on Charlie Peace (burglar and murderer and, according to the website, 'one of Britain's most notorious criminals') and another on Hawley Harvey Crippen (more commonly known as 'Dr Crippen') despite the fact that Crippen was not tried or incarcerated at Nottingham. In other museums that do not have the benefit of celebrity or (in)famous inmates, exhibitions or displays emphasise the most serious or unusual offenders, generally murderers, for example Bodmin's Selina Wadge (executed in 1752 for the murder of her own child), Oxford Castle's Mary Blandy (executed for the murder of her father) and Beaumaris Gaol's Richard Rowlands (executed in 1862 for the murder of his father-in-law). The association between the prison and the most serious and dangerous offenders is also accentuated through other museum events. In early 2014, for example, Nottingham Galleries of Justice website advertised a lecture series on murder. The lectures were delivered by a psychologist and academic, and thus were clearly intended to have an

\footnotetext{
${ }^{13}$ A good example here is Alcatraz. For the last 20 years or so there have been concerted efforts to market Alcatraz around the notion of 'freedom' rather than 'confinement' (with tour guides emphasising the island's important role as a nature reserve and, being the birthplace of the Red Power movement, as a Native American heritage site). However the tourist interpretation of the prison is fundamentally influenced by media depictions and tourists overwhelmingly visit 'the rock' to envisage the lives of those notorious inmates made legendary via Hollywood movies (Loo and Strange, 2000).

${ }^{14}$ Mitchell, referred to as the 'Dartmoor Axe man' (Times, December 13th, 1966: 1) was a friend - and possibly later victim - of Ronald and Reginald Kray, who allegedly arranged his escape from the prison in 1966. John George Haigh, English serial killer, otherwise known as the 'Acid bath murderer' was executed in 1949 (but not at Dartmoor).
} 
educational element, however the advertisement focused on aspects of murder such as 'famous women killers' and 'child killers', playing to the sense of the unusual, the sensational and the 'dangerous'.

It would be incorrect to claim that, in spotlighting the 'extraordinary' prisoner, prison tourist sites fail to recognise the vast and mundane bodies of poor and petty criminals that have historically filled prison spaces. In many venues the poverty and deprivation of the inmate population is emphasized both in visual and narrative form. However on prison tourist websites these prisoners, and their crimes, just as easily become repackaged as familiar stereotypes, 'cut off from antecedent events, social ties or political motivation' (Lyon, 2006: 44). For example, the York Castle Prison site introduces visitors to a range of 'ordinary' prisoners including teenager Simon Hargreaves, who was imprisoned in 1829, awaiting a sentence of execution (later commuted to transportation for life) for the crime of burglary (stealing a boiled egg from a house). Despite the stark discrepancy between his minor offence and his excessive punishment, the website feature describes him as 'a troublemaker' and a ' $19^{\text {th }}$ century lager lout'. Not all portrayals of prisoners are as unsympathetic or decontextualized however. On the Bodmin Jail website, for example, the visitor can read a lengthy description of the case of Selina Wadge. Considerable detail is provided about her crime and her difficult social and personal circumstances are presented, to some degree, as mitigating factors. But even here an opportunity to plug into the sense of the unusual, sensational and dangerous is not lost. The account of Selina's case ends with the warning that '[h]er ghost still haunts the prison 
and tries to reach out to small children and instil feelings of guilt and remorse on pregnant women'. ${ }^{15}$

As a backdrop for the dramatized depiction of prisoners, websites often present a sensationalised, yet at the same time simplified and sanitised, version of prison history, facilitated by, what Eamonn Carrabine (2012) calls, a 'transfixation' with a range of exaggerated or 'imagined' realities of prison life. Exaggeration is primarily manifest through the prioritisation of the exceptional over the mundane. The routine and tedious day to day reality of prison life is supressed in favour of representations of 'spectacular' events such as escapes and violence. Despite only experiencing 12 escapes during its 69 year history, Inveraray Jail has a webpage dedicated to these breakouts. Oxford Castle advertises its '1000 years of murder, romance, betrayal, escape and execution'. Dartmoor's website emphasises famous escapes from the prison and a collection of prison weaponry. Arguably these depictions mirror the reality of prison life to some degree (whereby mundane existence is punctuated by exceptional, sometimes violent, episodes). However, they can also 'erase as much as they reveal' (Walby and Piche, 2011: 452) because the 'extraordinary' episodes depicted, or inferred, on most websites are of a very different nature to those that occur in reality. Whilst websites present stories of escapes and murders there is a visual absence and a narrative silence around other, much more common, forms of prison conflict and violence. Incidents of suicide and self-harm in custody are far more common than escapes ${ }^{16}$ and murders ${ }^{17}$ but these

\footnotetext{
${ }^{15}$ It is interesting to note that there are 24 visitor responses to this story on the website of which 20 are comments on visitors' supernatural experiences at the prison. None of the responses make reference to Selina's particular case and only one refers to the harshness of former punishments, but only to note that 'times have changed and the justice system is so much better now'.

${ }^{16}$ There were 724 incidents of self-inflicted death and 194,384 incidents of self-harm in England and Wales compared with 42 escapes from prisons between 2003 and 2012 (this latter figure increases to 94 if escapes from prison escorts are included) (Prison Digest, 2011-12).

${ }^{17}$ There were 14 homicides in prisons in England and Wales between 2003 and 2012 (Ministry of Justice, 2012)
} 
events do not form a part of the dominant tourist narrative. To accentuate these aspects of the prison experience would be to set up a complex and contradictory discourse to the one that defines the prisoner as the deviant 'other'. Instead, in keeping with other media representations, prison violence is constructed as a result of individual choice and prisoners' psyche, as conflicts devoid of structural dimensions and disconnected from any form of state action.

Punishment within prison is another dominant theme on prison tourist websites and has become almost 'fetishized' in some areas of prison tourism. ${ }^{18}$ Unlike at previous times in the history of prison tourism, when objects perceived as appealing to gratuitous voyeurism were avoided, at least in official circles, now they are sought out and promoted. ${ }^{19}$ The Nottingham Galleries of Justice website invites visitors to:

[c]ome and be amazed by a new and exciting exhibition that takes you on a journey through the dark contents of Dr Massey's Cabinets of Crime.... The Executioner's Box (sic), the Scold's Bridle and the Whipping Frame ... amongst other criminal curiosities such as restraints, weapons, murderer's gravestones and coffins...[and to stand] on the creaking trapdoors from England's last operational gallows.

\footnotetext{
${ }^{18}$ Here we refer to official punishments administered within the prison (for example whipping, birching, solitary confinement cells, various forms of restraint and, in some cases, execution).

${ }^{19}$ Hence the current moves to open the 'Black Museum' or, more accurately the Crime Museum, in Scotland Yard, to the public. The museum contains a collection of artefacts from serious crimes and criminals and has developed over more than a century. It has never been opened to the public, although that looks likely to change in the near future (Independent 25 December 2014).
} 
The Inveraray Gaol website informs tourists that they can try out the 'crank' and the 'whipping table'. ${ }^{20}$ At Bodmin they can experience 'the only working execution pit in the UK' and can '[l]ook and learn how many of the Jail's condemned were dispatched to eternity with the 'Long Drop". Oxford Castle encourages visitors to try out the 'traditional hard labour punishments'. Ripon Gaol's exhibits include a pillary and whipping post and visitors are encouraged to imagine 'the horror of being set in the pillory, strapped in a restraint chair or hung in chains. [They can] turn the crank, carry out shot drill or work the treadmill'. Whilst in Ruthin they can experience 'the punishments [prisoners] suffered', and can '[e]xplore the...punishment, 'dark' and condemned cells'.

Kavanagh (1989) argues that museum artefacts undergo modifications in meaning and interpretation over time. Through their use in prison museums, punishment artefacts have clearly shifted from their original state as objects of real pain and terror, sometimes to relics of a shameful period of penal history but more commonly to forms of entertainment and pleasure. ${ }^{21}$

When defining the prisoner and their treatment in prison, the museum representation, by a process of contra-opposition, simultaneously defines the audience. The potential problem here is two-fold. First, such a presentation allows the audience to be too easily reconciled with the horrors of past penality. Museum artefacts can be emotional triggers or sources of symbolic messages whose interpretation is dependent on the personal experience of the viewer and the context in which the object is presented (Kavanagh, 1989). Reconstructing a whipping frame,

\footnotetext{
${ }^{20}$ Interestingly the crank at Inveraray Gaol is not a reproduction but an original artefact so having a more explicit educational purpose as the visitor can indeed get closer to the experience of this form of hard labour rather than a mock, semi-humorous interlude on the whipping table.

${ }^{21}$ Under the 'recent verdicts' link on the Inveraray website, visitors express their enjoyment of their 'hands on' experience of punishment artefacts. One noted that she 'especially liked trying the hammock and the birching table'. Another commented 'my boyfriend seemed very amused at being able to lock me up and even whip $\mathrm{me}^{\prime}$
} 
a birching table or a gallows as family entertainment is only possible if the audience is permitted to remain detached from the reality of its origins and/or comfortable in accepting the original recipients of such punishments were deserving of their fate. Second, the presentation of such artefacts without political, structural or social context can represent a process of 'memorialisation' (Walby and Piche, 2011) whereby the harshness of punishment is presented as simply a bygone aspect of imprisonment and worthy of commemoration. Most prison tourist sites emphasise their grim histories. In both graphics and narrative form, websites foreground the abject conditions experienced by many prisoners and the barbaric punishments inflicted upon them. But this depiction generally evokes the state-sanctioned narrative of penal progressivism which infers that things were harsh then but they are alright now. Or, indeed, the harsher the punishment then, the more lenient and compassionate punishment is now by comparison. As stated on the York Castle Prison website:

Life in Georgian England was far harsher than it is today - so you can imagine that life behind bars was even worse. The Prison was divided into different floors, with the debtors above and the felons in the worst conditions below. They would sleep twelve or fifteen to a cell... The poorest of them would live on bread and water, sleep on bare boards, and wear nothing but rags in the unheated cells.

Discourses of reform are commonplace in prison tourism. As Levin (2005: 78) argues, museum exhibitions that focus on marginalised groups are necessarily 
shaped by the 'institution's past and present relationship to the dominant group'. Thus, they reproduce cultural norms and values through the presentation of homogeneous and hegemonic narratives and the exclusion of competing accounts. ${ }^{22}$ For Bennett (1995, cited in Levin, 2005) this carefully selected form of display is a mechanism of social control, not through obvious forms of dominance but through a cajoling of the public into complicity with a dominant narrative. ${ }^{23}$ Where prisons are concerned, this dominant narrative is constructed around discourses of reform and progressivism. Prisons persist because of the popular belief that they can 'work', providing security for the law abiding whilst imposing punishment on, and offering rehabilitation for, offenders (Drake, 2014). In other words, they must be presented, and perceived, as legitimate. Unlike at some dark tourist sites, prisoners are generally not perceived as victims worthy of commemoration and remembrance, no matter how harshly or unjustly they were treated. Tourists must be able to witness the terribleness of the past without discomfort or guilt. The obvious way these requirements can be fulfilled is by emphasizing the injustice of the prisons of the past alongside the rightfulness and efficacy of contemporary institutions.

Dartmoor presents a good example. The Dartmoor prison museum website claims to reveal the institution's 200 year history. However, despite Dartmoor being recommended for closure in 2013, having been referred to as the 'prison that time forgot' (Anne Owers, then Chief Inspector of Prisons, quoted in Independent, 2002) and 'no longer the sort of prison we should have in this century' (Juliet Lyons, quoted on BBC, 2010), the website opens with a message from Governor Terry Witton

\footnotetext{
${ }^{22}$ In Kilmainham for example, the experiences of 'ordinary' criminals have been marginalised in favour of a focus on Nationalists (O'Brien, 1996; Levin, 2005) thus class-based social injustices are obscured by a narration dominated by political oppression.

${ }^{23}$ Bennett uses the example of the Great London Exhibition of 1851 to highlight how visitors were inveigled into complicity with industrial 'progress'.
} 
which clearly illustrates how representations of the prison in the museum do not disrupt the dominant narrative about penal progressivism and utility. He states:

\begin{abstract}
Dartmoor has a long and fascinating history that has seen many changes in its fortunes. But it is also at the cutting edge of modern penal practice, developing ways to help offenders change their lives and protect the public (emphasis added).
\end{abstract}

The progressive rhetoric is clearly embraced by visitors. One customer review on the site notes: "This museum is superb... It gave me an insight on how much prisons have changed over the years". Others state how it is "[a]mazing to be able to see the way people lived only half a century ago" and "what brutal places prisons were". The exhibitions are described as providing "...a very real sense of what prison was like" and as a "real eye opener as to what prisoners had to go through years ago [when] they really were punished". ${ }^{24}$

Undoubtedly physical conditions in prisons improved due to the work of nineteenth century reformers but the story of prisoner hardship and suffering did not end with the rise and consolidation of this movement. As Foucault conceptualised, the 'reformed' prisons aimed "not to punish less, but to punish better, to punish with an attenuated severity perhaps, but...to punish with more universality and necessity; to insert the power to punish more deeply into the social body" (Foucault, 1977: 82).

In keeping with the broader thanatopic tradition, perhaps the most prevalent thematic device of all in prison museums is death. 'Thanatourism' largely focuses on 'unquiet' deaths (Walter, 2009) - the deaths of those who have died in vain through

\footnotetext{
${ }^{24}$ Italics in these quotations indicate 'emphasis added'.
} 
meaningless action (such as murders), unjust wars or conflicts (Rwanda or Cambodia's 'Killing Fields') or other forms of difficult to comprehend violence (Auschwitz-Birkenau being an obvious example). Thanatourist venues enable the public to establish different kinds of relationships with the dead. For example, some offer a means of information and education whilst others represent opportunities for remembrance or memorials. In prison tourism, visitors encounter death partly through depictions of execution, but more commonly tourists are offered more 'intimate' interaction through the paranormal and elements of the supernatural. As Cooke (2000) observes, prisons are spaces which present intense and specific connections between life, death and structure: visitors can walk into cells where people suffered and sometimes died and they can occupy the spaces and touch the artefacts of execution. In prison the layers of history, meaning and imagination that have built up over time appear more concrete; as the present architectural space is “haunted' by these earlier texts (Fiddler 2011: 94). Arguably in prison museums this is why people 'talk more readily of ghosts than in conventional museums' (Cooke, 2000: 6).

Prison museums offer a forum for mediation between the living and the dead but, other than in those museums with an explicitly politicised identity, such as Kilmainham, this is not in the form of memorial or remembrance. Rather, representations of the dead are used purely for entertainment. Most prisons offer 'ghost tours', 'spooky' Halloween events or 'haunted prison' experiences (Crumlin Road Gaol, Nottingham Galleries of Justice, Inveraray Gaol, the Clink, Derby Gaol, Bodmin) and many claim to be amongst the 'most haunted' buildings in their respective counties (Nottingham, Inveraray, the Clink and Derby Gaol all make this claim). In this form, death becomes 'a theatre for the living' (Seltzer, 1998, in 
Penfold-Mounce, 2010: 254) and, arguably, serves two purposes. First, the focus on the paranormal falsely enhances the 'extra-ordinariness' of the prison and the 'otherness' of its inmates, further dislocating the audience from an authentic history. Second, although seemingly offering a means for the visitor to connect with the prisoners of history, in reality the conjuring of 'ghosts' serves to disconnect and separate the present from past. Just like the dominant architectural form that visitors encounter and, moreover, expect to encounter in prison tourism, prisoner ghosts represent something unnerving and unsettling yet simultaneously familiar and appeasing. Emphasising the rhetoric of penal progressivism, they are relics of a distant past, unable to rest in death due to their miserable existence in conditions that no longer endure, for as conditions improve, the 'souls' of the dead are clearly not so restless. A paranormal event recounted on the Inverary website explains how the supernatural environment correlated with the changing conditions and uses of the prison.

In the old prison, Scott [from 'Ghostfinders'] felt that the area was dominated by a negative soul by the name of John.... In the new prison, Scott felt a different atmosphere. It seemed that conditions were much better and that there was more lenience towards the prisoners (emphasis added).

\section{Conclusion}

Prison museums in the early twenty-first century, as in the past, enjoy a degree of latitude in that the form of punishment they exhibit is depicted as deriving from a less civilised and more deterrent past, enabling comparison with a supposed more enlightened but less questioned present. The space between these two chronologically-based concepts facilitates a distancing from the real experience and 
pains of incarceration; a disjuncture which allows punishment to be depicted and experienced partly as a form of entertainment. Jenkinson notes that the lack of political critique in many museums stems from the desire to avoid controversy and to maintain a sense of balance and fair play (1989: 144). That may be understandable in some types of museums but the notions of 'fair play' and a 'balanced perspective' is problematic for prison museums. ${ }^{25}$ Prisons are not neutral, de-political, socially balanced spaces. They never have been. They are institutions that have been historically defined by the state as the most apposite response to crime when, as historical and contemporary evidence demonstrates, they systematically inflict punishment onto the most vulnerable, the least powerful and the already excluded in society (Parenti, 1999; Sim, 2009; Scott, 2013; Wacquant, 2009).

Since we suggest that visitors' experience of prison museums has an impact on their perception of contemporary penal systems, this disjuncture between reality and representation has implications beyond the entrance to the prison museum. But Strange and Kempa (2003: 387) have commented that although the tourist commodification of the prison can serve to simplify and depoliticise the realities of penality and penal history 'it does not preclude the presentation of counterhegemonic stories or tales of injustice'. Perhaps to achieve this, prison museums need to turn away from the desire to present 'balanced' histories, and even from the quest for 'authenticity' in favour of, what Julia Clark (curator of Port Arthur in Australia) terms, a goal of inclusive 'integrity' (in Wilson, 2008: 58). To achieve 'inclusive integrity' we might look to testimonies and narratives from those who have been, and continue to be, 'othered' by the prison. Not solely testimonies of shame,

\footnotetext{
${ }^{25}$ Just as it would be problematic (indeed unthinkable) for other types of 'dark' museums or sites that attempt to commemorate, or educate the public on, institutions or events that caused human suffering, harm and/or death (for example the various Holocaust or genocide museums around the world).
} 
remorse and redemption but testimonies of contestation and resistance. Testimonies which refuse to 'de-politicise' the institution. Historically this is not an easy task, since prisoners have been among the least able to leave their voice to posterity. Nevertheless, advances have been made in historical research to present the perspective of those incarcerated in the past and their social and economic contexts (for example Ballinger, 2000; Barton, 2011; Brown and Clare, 2005; Morgan, 1999; Godfrey, Cox and Farrell, 2007); these could be used to establish dedicated museums which reflect the whole gamut of experience in that prison, rather than to reiterate a simplified and centralised version of the penal past repeating longstanding conventional stereotypes. 


\section{Bibliography}

Belfast Newsletter

Daily Mirror

Dundee Courier

Essex Standard and General Advertiser for the Eastern Counties

Illustrated London News

Lloyd's Weekly

Manchester Guardian

The Times

Tit Bits

Anon, A Guide to Lincoln Castle and Grounds (W.H.Leary, 1898). Thank you to Helen Bates and Susan Payne of the Lincoln Castle Revealed project for their help locating these sources.

Anon, Guide to Lincoln Castle (Lincolnshire Chronicle Ltd, 1927).

Anon, Lincoln Castle Official Guide (LSG Printers, 1970s?).

http://www.shipsuccess.com/content/Home.html (accessed 20 July 2014)

Adams, J (2001) "'The Wildest Show in the South: Tourism and Incarceration at Angola', The Drama Review, Vol 45, No 2, pp94-108.

Arnold, C (2008), Bedlam: London and its Mad. London, UK: Pocket Books.

Balfour, J. S. (1907) My Prison Life. London: Chapman and Hall

Ballinger, A. (2000) Dead Woman Walking: Executed Women in England and Wales, 1900-1955. Aldershot: Ashgate.

Barton, A. (2011) 'A Woman's Place? Uncovering Maternalistic Forms of Governance in a 19th Century Reformatory', Family and Community History, 14 (2), pp89-104.

Barton, A. and Brown, A. (2011) 'Dartmoor: Penal and Cultural Icon', Howard Journal of Criminal Justice, Vol.50 (5): 478-491.

BBC. (2010) 'Dartmoor Jail "too old and isolated" reform trust says', 1 July. http://www.bbc.co.uk/news/10470561 
BBC News UK. (2013) Seven prison closures in England announced', 10 January. http://www.bbc.co.uk/news/uk-20969898

Bell, E. (2013) 'The prison Paradox in neoliberal Britain', in D. Scott (Ed) Why Prison? Cambridge, UK: Cambridge University Press

Bender, J. (1987) Imagining the Penitentiary: Fiction and the Architecture of Mind in Eighteenth Century England. Chicago, IL: University of Chicago Press.

Bennett, J (2006a) 'The Good, the Bad and the Ugly: The media in prison films', Howard Journal of Criminal Justice, Vol 45, No 2, pp97-115

Bennett, J (2006b) 'We might be locked up but we're not thick: Rex Bloomstein's Kids Behind Bars', Crime, Media, Culture, Vol 2, No 3, pp268-285.

Black, J. (2003) British Abroad. Stroud, UK: The History Press.

Bosworth, M (1999) Engendering Resistance: Agency and Power in Women's Prisons. Farnham, UK: Ashgate

Brodie, A et al (2002) English Prisons: An Architectural History, English Heritage.

Brodie, A. (2014) 'The Georgian Prison: Inquisitive and Investigative Tourism', forthcoming Prison Service Journal, 216 November, pp.44-49.

Brown, A. (2003) English Society and the Prison: Time, Culture and Politics in the Development of the Modern Prison, 1850-1920. Woodbridge, UK: Boydell Press.

Brown, A. and Clare, E. (2005) A History of Experience: Exploring Prisoners' Accounts of Incarceration', in C. Emsley (Ed.) The Persistent Prison: Problems, Images and Alternatives. London, UK: Francis Boutle Publishers.

Brown M (2009) The Culture of Punishment: Prison, Society and Spectacle. New York, NY: New York University Press.

Burkart, A.J. and Medlik, S. (1981) Tourism: Past, Present and Future. Oxford, UK: Heinemann Professional Publishing.

Buddhabhumbhitak, K. (2010) 'Tourism Immersion or Tourist Gaze' in P. Burns, C. Palmer and J. Lester (Ed) Tourism and Visual Culture: Theories and Concepts. Wallingford, UK: CAB International.

Burnett, R. and Maruna, S. (2004) 'So 'Prison Works', Does It? The Criminal Careers of 130 Men Released from Prison under Home Secretary, Michael Howard', Howard Journal of Criminal Justice, 43 (4), pp.390-404.

Carrabine, E. (2012) 'Telling Prison Stories' in L. Cheliotis (Ed) The Arts of Imprsionment: Control, Resistance and Empowerment. Farnham, UK: Ashgate 
Cheliotis, L. (2010) 'The Ambivalent Consequences of Visibility: Crime and Prisons in the Mass Media' Crime, Media, Culture, 6 (2) pp. 169-184.

Chibnall, S (2006) 'The Anti-Heroines of Holloway: The Prison Films of Joan Henry and J. Lee Thompson', in P. Mason (Ed) Captured by the Media: Prison Discourse in Popular Culture. Cullompton, UK: Willan. Pp. 172-190.

Cooke, P. (2000) 'Kilmainham Gaol: Interpreting Irish Nationalism and Republicanism', Open Museum Journal, 2, http://pandora.nla.gov.au/pan/10293/200201200000/amol.org.au/craft/omjournal/volume2/cooke.pdf

Corston, J. (2007) The Corston Report: A Review of Women with Particular Vulnerabilities in the Criminal Justice System. London, UK: Home Office.

Cross, G. and Walton, J.K. (2005) The Playful Crowd: Peasure Places in the Twentieth Century. New York, NY: Columbia University Press.

Davis, A. (2003) Are Prisons Obsolete? New York, NY: Seven Stories Press.

Digital Antiquaria, www.digitalantiquaria.com.

Downes, D. (2007) 'Visions of Penal Control in the Netherlands' in M. Tonry (Ed), Punishment and Politics in Comparative Perspective. Chicago, IL: University of Chicago Press. Pp 93-125.

Drake, D. (2014) Prisons, Punishment and the Pursuit of Security. London: Palgrave Macmillan.

Evans, R. (1982/2010) Fabrication of Virtue: English Prison Architecture, 1750-1840. Cambridge: Cambridge University Press.

Exploring $20^{\text {th }}$ Century London, 'Suffragette stand at the Women's, Knightsbridge Exhibition' http://www.20thcenturylondon.org.uk/mol-in115.

Fiddler, M. (2011) 'A 'system of light before being a figure of stone': The phantasmagoric prison', Crime Media Culture 7 (1), pp. 83-97.

Fiddler, M. (2013) 'Interview: Saul Hewish' in A.Brown and A.Barton (eds.) special edition on The Prison and the Public, Prison Service Journal. 210 (Nov), pp. 39-43.

Foley, M. and Lennon, J. (1996) 'JFK and Dark Tourism: Heart of Darkness', Journal of International Heritage Studies. 2 (4), pp. 198-211.

Foucault, M. (1977) Discipline and Punish: The Birth of the Prison. New York, NY: Random House.

Godfrey, B., Cox, D. and Farrall, S. (2007) Criminal Lives: Family, Employment and Offending. Clarendon Series in Criminology, Oxford, UK: Oxford University Press. 
Independent (2003) 'Brixton, Holloway and Dartmoor jails are labelled the worst in England', 25 July. http://www.independent.co.uk/news/uk/crime/brixton-hollowayand-dartmoor-jails-are-labelled-the-worst-in-england-97602.html\#

Jarvis, B. (2006) 'The Violence of Images: Inside the Prison TV Drama OZ, in P. Mason (Ed) Captured by the Media: Prison Discourse in Popular Culture. Cullompton, UK: Willan. Pp.154-171.

Jenkinson, P, (1989) 'Material Culture, People's History and Populism: Where do we go from here?' in S. Pearce (Ed) Museum Studies in Material Culture. London, UK: Leicester University Press.

Jewkes, Y. (2006) 'Creating a Stir? Prisons, Popular Media and the Power to Reform', in in P. Mason (Ed) Captured by the Media: Prison Discourse in Popular Culture. Cullompton, UK: Willan. Pp.137-153.

Jewkes, Y. (2012) 'Aesthetics and An-Aesthetics: The Architecture of Incarceration' in L. Cheliotis (Ed), The Arts of Imprisonment: Control, Resistance, Empowerment. Farnham: Ashgate

Johnston, H (2006) "'Buried Alive": Representation of the Separate System in Victorian England' in P. Mason (Ed) Captured by the Media: Prison Discourses in Popular Culture. Cullompton: Willan.

Kavanagh, G, (1989) 'Objects as Evidence, or Not?' in S. Pearce (Ed) Museum Studies in Material Culture. London, UK: Leicester University Press.

Kravchyna V \& Hastings S K (2002) 'Informational value of museum web-sites', First Monday, 7 (2), http://ojphi.org/ojs/index.php/fm/article/view/929/851\#k1 (accessed: 1 October 2014).

Lacey N (2008) The Prisoners' Dilemma: Political Economy and Punishment in Contemporary Democracies. Cambridge, UK: Cambridge University Press.

Levin, A. (2005) 'Irish Museums and the Rhetoric of Nation', Journal of the Midwest Modern Language Association, 38 (2) pp. 78-92.

Liebling, A. (1995) 'Vulnerability and Prison Suicide', British Journal of Criminology, 35 (2), pp.173-187.

Liebling, A. (1999) 'Prison Suicide and Prisoner Coping', Crime and Justice, 26, pp. 283-359.

Loo, T. and Strange, C. (2000) "Rock prison of Liberation": Alcatraz Island and the American Imagination', Radical History Review, 78, pp27-56.

Lyon, D. (2006) '9/11, Synopticon and Scopophilia: Watching and Being Watched' in K. Haggerty and R. Ericson (Ed) The New Politics of Surveillance and Visibility. Toronto, CA: University of Toronto Press. 
Macartney, W. (1936) Walls have Mouths: A Record of Ten Years' Penal Servitude, London: Camelot Press.

Morgan, S (1999) 'Prison Lives: Critical Issues in Reading Prisoner Autobiography', Howard Journal of Criminal Justice 38 (3): 328-40.

Marty, P. (2007) 'Museum Websites and Museum Visitors: Before and After the Museum Visit', Museum Management and Curatorship 22 (4), pp.337360.

Mason, P. (2003) Criminal Visions: Media Representations of Crime and Justice. Cullompton, UK: Willan.

Mason, P. (2006a) 'Prison Decayed: Cinematic Penal Discourse and Populsim 19952005', Social Semiotics, 16 (4), pp607-626.

Mason, P. (Ed, 2006b) Captured by the Media: Prison Discourse in Popular Culture, Cullompton, UK: Willan.

Mathiesen, T. (2006) Prison on Trial, 3rd Edition. Winchester, UK: Waterside Press.

Mathiesen, T. (2013) 'Foreword: On Stemming the Tide' in D. Scott (Ed) Why Prison? Cambridge, UK: Cambridge University Press.

Ministry of Justice (2012) 'Safety in Custody Statistics England and Wales' https://www.gov.uk/government/uploads/system/uploads/attachment data/file/19243 1/safety-custody-dec-2012.pdf (accessed: 1 Sept 2014)

Monteresso, S. (2009) 'Punitive Criminal Justice Policy in Contemporary Society', QUT Law Review, 9 (1), pp. 13-25.

Morris, N. and Rothman, D. (1998) 'Introduction' in N. Morris and D. Rothman (Ed) The Oxford History of the Prison: The Practice of Punishment in Western Society. Oxford, UK: Oxford University Press.

O'Brien, A.(1996) 'Marketing and Managing Colonial Spectacle as National History: In the Belly of the Archive', South Atlantic Quarterly, 95 (10), pp. 103-44.

O’Dwyer, R. (2010) 'The Wilderness Years': Kilmainham Gaol, 1924-1960', History Ireland Vol.18 (6) Nov/Dec, pp. 40-43.

O'Sullivan, S (2001) 'Representations of Prison in Nineties Hollywood Cinema: From Con Air to the Shawshank Redemption', Howard Journal of Criminal Justice, 40 (4), pp317-334.

Parenti, C. (1999) Lockdown America Lockdown America: Police and Prisons in the Age of Crisis. Phoenix, AZ: Vergo. 
Penfold-Mounce, R. (2010) 'Consuming Criminal Corpses' Mortality, vol.15 (3), pp. 250-265.

Pratt, J. (2002) Punishment and Civilization: Penal Tolerance and Intolerance in Modern Society. London: Sage.

Prison Digest (2011-12) https://www.gov.uk/...data/.../prison-performance-digest2011-12.xls (accessed: 23 July 2014).

Ryan, M. (2006) 'Red Tops, Populists and the Irresistible rise of the Public Voice(s)' in P. Mason (Ed) Captured by the Media: Prison Discourse in Popular Culture. Cullompton, UK: Willan. Pp.31-47.

Scott, D. (2013) 'Why Prison? Posing the Question' in Scott, D. (Ed) Why Prison? Cambridge, UK: Cambridge University Press.

Scott, D. and Codd, H. (2010) Controversial Issues in Prison. Berkshire, UK: Open University Press.

Sharpley, R. and Stone, P. R. (2009) The Darker Side of Travel: The Theory and Practice of Dark Tourism. Bristol, UK: Channel View Publications

Sharpley, R. (2009) 'Shedding Light on Dark Tourism: An Introduction' in R. Sharpley and P. Stone (Eds) The Darker Side of Travel: The theory and Practice of Dark Tourism. Bristol: Channel View Publications.

Sim, J. (2009) Punishment and Prisons: Power and the Carceral State. London, UK: Sage.

Simon, M. and Feeley, J. (1992) 'The New Penology: Notes on the Emerging Strategy of Corrections and its Implications' Criminology, 30(4), pp. 449-474.

Sparks, R. (1992) Television and the Drama of Crime. Buckingham, UK: Open University Press.

Stone, P. (2006) 'A Dark Tourism Spectrum: Towards a Typology of Death and Macabre Related Tourist Sites, Attractions and Exhibitions' Tourism, 54 (22), pp. 145-160.

Strange, C. and Kempa, M. (2003) 'Shades of dark tourism: Alcatraz and Robben Island' Annals of Tourism Research, 30 (2) pp.386-405.

Urry, J. (1990) The Tourist Gaze, London: Sage.

Wacquant, L.(2009) Punishing the Poor: The Neo-liberal Government of Social Insecurity. Durham, NC: Duke University Press.

Walby, K. and Piche, J. (2011) 'The Polysemy of Punishment Memorialisation: Dark Tourism and Ontario's penal History Museums', Punishment and Society, 13(4), pp451-472. 
Walter, T. (2009) 'Dark Tourism: Mediating Between the Dead and the Living', in R. Sharpley and P. Stone (Eds) The Darker Side of Travel: The theory and Practice of Dark Tourism. Bristol: Channel View Publications.

Walton, J.K. (ed.). (2005) Histories of Tourism: Representation, Identity and Conflict, Bristol, UK: Channel View Publications.

Welch, M .(2005) Ironies of Imprisonment, Thousand Oaks, CA: Sage.

Welch, M. (2012) 'Penal tourism and the 'dream of order': Exhibiting early penology in Argentina and Australia', Criminology \& Criminal Justice, 14 (5), pp584-615.

Welch, M. (2013) 'Penal Tourism and a tale of four cities: Reflecting on the museum effect in London, Syndey, Melbourne and Buenos Airies, Criminology \& Criminal Justice, 13 (5), pp479 - 505.

Welch, M. and Mauare, M. (2011) 'Penal tourism in Argentina: Bridging Foucauldian and neo-Durkheimian perspectives', Theoretical Criminology, 15 (4), pp401-425.

White, J. (2009) 'Pain and Degradation in Georgian London: Life in the Marshalsea Prison', History Workshop Journal, 86 (1), p76.

Wilson, J.Z. (2004) 'Dark tourism and the celebrity prisoner: Front and back regions in representations of an Australian historical prison' Journal of Australian Studies, 28 (82), pp171-173.

Wilson, J. Z. (2008) Prison: Cultural Memory and Dark Tourism. New York, NY: Peter Lang.

Wright, P. (2000) 'The Cultural Commodification of Prisons', Social Justice, 27 (3), pp15-21.

\section{Prison Tourist Websites}

Beaumaris Gaol http://www.visitanglesey.co.uk/en/things-to-do/activities/beaumarisgaol/

Bodmin Gaol http://www.bodminjail.org/

Clink Prison Museum www.clink.co.uk/

Crumlin Road Gaol www.crumlinroadgaol.com/

Dartmoor Prison Museum http://www.dartmoor-prison.co.uk/

Derby Gaol www.derbygaol.com/

Inveraray Gaol www.inverarayjail.co.uk/ 
Littledean Jail www.littledeanjail.com/

Nottingham Galleries of Justice www.galleriesofjustice.org.uk/

Ripon Gaol http://riponmuseums.co.uk/

Ruthin Gaol https://www.denbighshire.gov.uk/en/visitor/places-to-visit/museumsand-historic-houses/ruthin-gaol.aspx

York Castle Prison www.yorkcastleprison.org.uk 